\section{СТАТИСТИКА, ЕСЕП ЖӘНЕ АУДИТ}

\section{СТАТИСТИКА, УЧЕТ И АУДИТ}

\section{STATISTICS, ACCOUNT AND AUDIT}

ISSN 1563-2415

Ежеквартальный научнопрактический журнал издается с 1999 года.

№ 1(84) 2022

Учредитель «Алматинский гуманитарно-экономический университет»

Алматинский гуманитарно-экономический университет

Главный редактор

Досаева С.К.

Заместители гл. редактора:

Корвяков В.А. - д.п.н., проф., ректор АГЭУ

Сейтхамзина Г.Ж. - к.э.н., проф., проректор по науке и инновациям АГЭУ

\section{Члены редколлегии:}

Амирханова Г.А. - доктор $\mathrm{PhD}$, снс ИИВТ КН МОН РК, г.Нур-Султан, Казахстан

Бекенова Л.М. - к.э.Н., профессор, проректор по академической работе АГЭУ

Дауренбеков А.К. - к.э.н., проф. АГЭУ, г. Алматы, Казахстан

Дырка Стефан - д.э.н., проф., Верхнесилезский экономический Университет имени Вой- цеха Корфанти в Катовицах, Польша

Ерж⿻анов М.С. - д.э.н., проф., партнер «Grant Thornton», г.Алматы, Казахстан

Ешпанова Д.Д. - к.э.н., доцент кафедры "Учет, аудит и статистика" АГЭУ, г.Алматы, Казахстан

Макыш С.Б. - д.э.н., проф., декан экономического факультета, ЕНУ им.Л.Н.Гумилева, г.Нур-Султан, Казахстан

Мезенцева T.M. - д.э.н., профессор департамента учета, анализа и аудита Финансового Университета при правительстве РФ, г.Москва, Россия

Назарова В.Л. - Д.э.н., проф., зав. кафедрой "Учет, аудит и статистика" АГЭУ, г.Алматы, Казахстан

Рахметова P.У. - д.э.н, проф., Туран - Астана, Нурсултан, Казахстан

Сейдахметова Ф.С. - д.э.н., проф. кафедры "Учет, аудит и статистика" АГЭУ, г.Алматы, Казахстан

Taunoв T.A. - к.э.н., проф., АГЭУ, г.Алматы, Казахстан

Тайгашинова К.T. - д.э.Н., проф кафедры "Учет, аудит и статистика", АГЭУ, г.Алматы, Казахстан

Шокаманов Ю.К. - Д.э.н., проф., г.Нур-Султан, Казахстан

\section{Издательский центр}

Алматинского гуманитарно-

экономического университета

050035, г.Алматы,

ул.Жандосова, 59,

тел: +7 7273095820 ,

$+77273095815$

факс: + 77273093000

e-mail: zhurnal.aesa.99@mail.ru

www.journal.ageu.kz, www.ageu.kz

Ответственный за выпуск журнала Айтжанова Н.M.

Подписано в печать: 26.01.2022г.

Формат 70x108 1/16.

Бумага офсетная.

Тираж 300 экз.

\section{ИП «Аруна»}

г.Алматы, Алмалинский район, ул. Нурмакова, 26/195 кв. 49 e-mail: mail: iparuna@yandex.ru 
ISSN 1563-2415

Учреждение «Алматинский гуманитарно-экономический университет», 050035, г. Алматы, ул. Жандосова, 59, тел.(727) 309-58-20, 309-58-15, вн. 138 e-mail: zhurnal.aesa.99@mail.ru, aesa2005@mail.ru

Website: journal.ageu.kz, www.ageu.kz

Регистрационное свидетельство № 9099-Ж от 25.03.2008 г. выдано Министерством культуры и информации Республики Казахстан, Комитетом информации и архивов

Журнал включен в Российский индекс научного цитирования (РИНЦ) и размещается в научной электронной библиотеке (WWW.ELIBRARY.RU) (Лицензионный договор с ООО «НЭБ» № 133-03/2016 г.Москва 11 марта 2016 г.). 
Раман Ибрахим, Сюзана Бахарудин

МЕЛИМАУ ПОЛИТЕХНИКАЛЫҚ ИНСТИТУТЫНДА КОВИД-19

ПАНДЕМИЯСЫ КЕЗІНДЕ СИНХРОНДАЛҒАН ОНЛАЙН ОҚЫТУҒА

КЕНЕТ ӨТУ: ИНЖЕНЕРЛІК ФАКУЛЬТЕТІ СТУДЕНТТЕРІ

ПЕРСПЕКТИВАСЫН САНДЫК ЗЕРТТЕУ ...

Нориымах Осман

4IR ЭЛЕМЕНТТЕРІН ҚОЛДАНУ АРҚЫЛЫ ТЖКБ ЦИФРЛАНДЫРУ.

Тан Си Мин

ЦИФРЛІК МІНЕЗ-ҚҰЛЫҚТЫ ДАМЫТУ ЖӘНЕ МУЛЬТИФИКАЦИЯ МЕН ИННОВАЦИЯЛЫҚ ОҚЫТУ ҚҰРАЛЫ РЕТІНДЕ ИНТЕГРАЦИЯЛАУ:

ОҚУДАҒЫ СТУДЕНТТЕРДІН МІНЕЗ-ҚҰЛҚЫНА ӘСЕРІ.

\section{Тео Пей Киан}

ӨНДІРІСТІК СТУДЕНТТЕРДІ ОҚУ ТИІМДІЛІГІНЕ ОҚУ

ИННОВАЦИЯЛАРЫНЫҢ ӘСЕРІ ЖОҒАРЫ ОҚУ ОҚУЫНДАҒЫ

ДИЗАЙН.....

Дви Вахюнинсси, Сламет Утомо, Шри Сурачми, Сажида Досаева

КОВИД-19 ПАНДЕМИЯСЫ КЕЗІНДЕ ОНЛАЙН ОҚЫТУДЫН САПАСЫН

АРТТЫРУДАҒЫ КӨШБАСШЫНЫН РӨЛІ.

А.Адельбаева, А. Бекметова

АЗЫҚ-ТҮЛІКПЕН МОЛЫҚТЫРУДЫ ҚАМТАМАСЫЗ ЕТУ ҮШІН

АГРАРЛЫҚ НАРЫҚТЫ РЕТТЕУ.

А. Джумабаева, Д. Бабаш, А.Кенджасарова, Р.Арзикулова

ҚАЗАҚСТАННЫН АЗЫҚ-ТҮЛІК ҚАУІПСІЗДІГІН ҚАМТАМАСЫЗ ЕТУ:

ТЕОРИЯ, ӘДІСТЕМЕ ЖӘНЕ ПРАКТИКА

А. Нуртаева, С. Айткулова, А.Садвакасова, А.Кұрмантаева

КОММЕРЦИЯЛЫҚ БАНКТЕРДЕГІ ТӘУЕКЕЛДЕРДІ БАСҚАРУ ЖҮЙ-

ЕСІНІН ТИІМДІЛІГІН ТАЛДАУ.

\section{А.Рамазанов, С.Базылхан}

ҚОНАҚЖАЙЛЫЛЫҚТЫН КОНЦЕПТУАЛДЫҚ НЕГІЗДЕРІ.

А.Рамазанов, Ж.Куралов

ҚОНАҚ ҮЙ ІСІНІҢ ЭКОНОМИКАЛЫҚ СИПАТТАМАСЫ.

II.A. Topzaeвa

КОМПАНИЯ ҚЫЗМЕТІНДЕГІ ИНТЕРНЕТ МАРКЕТИНГ 


\section{СОДЕРЖАНИЕ}

Раман Ибрагим, Сюзана Бахарудин

ВНЕЗАПНЫЙ ПЕРЕХОД К СИНХРОНИЗИРОВАННОМУ ОНЛАЙНОБУЧЕНИЮ ВО ВРЕМЯ ПАНДЕМИИ COVID-19 В ПОЛИТЕХНИЧЕСКОМ ИНСТИТУТЕ МЕРЛИМАУ: КОЛИЧЕСТВЕННОЕ ИССЛЕДОВАНИЕ ПЕРСПЕКТИВ СТУДЕНТОВ ФАКУЛЬТЕТА МАШИНОСТРОЕНИЯ.............. 6

Норшыммах Осман

ОЦИФРОВКА ТVЕТ С ИСПОЛЬЗОВАНИЕМ ЭЛЕМЕНТОВ 4IR.

Тан Си Мин

РАЗРАБОТКА ЦИФРОВОГО ПОВЕДЕНИЯ И ИНТЕГРИРОВАНИЕ С МУЛЬТИФИКАЦИЕЙ В КАЧЕСТВЕ ИННОВАЦИОННОГО УЧЕБНОГО СРЕДСТВА: ВЛИЯНИЕ НА ПОВЕДЕНИЕ УЧАЩИХСЯ В ОБУЧЕНИИ.......

\section{Тео Пей Киан}

ВЛИЯНИЕ ОБУЧАЮЩИХ ИННОВАЦИЙ НА ЭФФЕКТИВНОСТЬ ОБУЧЕНИЯ СТУ ДЕНТОВ ПРОМЫШЛЕННЫХ ДИЗАЙН В ВЫСШЕМ ОБРАЗО-

ВАНИИ.

Dwi Wahyuningsih, Slamet Utomo, Sri Surachmi, Сажида Досаева

РОЛЬ РУКОВОДИТЕЛЯ В ПОВЫШЕНИИ КАЧЕСТВА ОНЛАЙН-

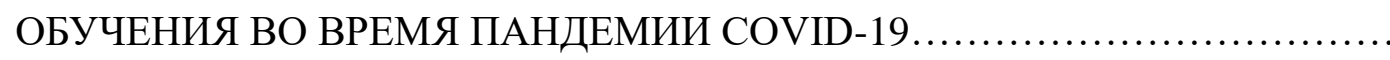

А.Адельбаева, А.Бекметова

РЕГУЛИРОВАНИЕ АГРАРНОГО РЫНКА ДЛЯ ОБЕСПЕЧЕНИЯ ПРОДО-

ВОЛЬСТВЕННОГО НАСЫЩЕНИЯ.

А. Джумабаева, Д. Бабаш, А.Кенджасарова, Р. Арзикулова ОБЕСПЕЧЕНИЕ ПРОДОВОЛЬСТВЕННОЙ БЕЗОПАСНОСТИ КАЗАХСТАНА: ТЕОРИЯ, МЕТОДОЛОГИЯ И ПРАКТИКА.

А. Нуртаева, С. Айткулова, А.Садвакасова А. Құрмантаева

АНАЛИЗ ЭФФЕКТИВНОСТИ СИСТЕМЫ УПРАВЛЕНИЯ РИСКАМИ В КОММЕРЧЕСКИХ БАНКАХ

\section{Рамазанов А., С.Базылхан}

КОНЦЕПТУАЛЬНЫЕ ОСНОВЫ ГОСТЕПРИИМСТВА.

Рамазанов А., Ж.Куралов

ЭКОНОМИЧЕСКИЕ ХАРАКТИРИСТИКИ ГОСТИНИЧНОГО ДЕЛА.

U.A Торгаева

ИНТЕРНЕТ - МАРКЕТИНГ В КОМПАНИЯХ 


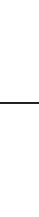

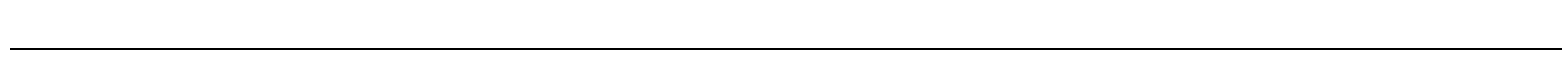

\section{Raman Ibrahim, Suzana Baharudin}

THE SUDDEN TRANSITION TO SYNCHRONIZED ONLINE LEARNING DURING THE COVID-19 PANDEMIC IN POLITEKNIK MERLIMAU: A QUANTITATIVE STUDY EXPLORING MECHANICAL ENGINEERING STUDENT'S PERSPECTIVES.

Norshymah Osman

DIGITALIZING TVET USING 4IR ELEMENTS.

Tan Si Min

DEVELOP DIGITAL STORYTELLING INTEGRATES WITH ANIMATION AS AN INNOVATIVE INSTRUCTIONAL TOOL: EFFECTS ON STUDENT'S BEHAVIOURAL ENGAGEMENT IN LEARNING.

Teo Pei Kian

THE EFFECT OF TEACHING INNOVATION ON LEARNING EFFECTIVENESS AMONG THE STUDENTS OF INDUSTRIAL

DESIGN IN HIGHER EDUCATION

Dwi Wahyuningsih, Slamet Utomo, Sri Surachmi, Sazhida Dossayeva

THE ROLE OF THE PRINCIPAL IN IMPROVING THE QUALITY OF ONLINE LEARNING DURING THE COVID-19 PANDEMIC

A. Adelbaeva Phd student, A. Bekmetova

REGULATION OF THE AGRICULTURAL MARKET TO ENSURE FOOD SATURATION

A. Dzhumabayeva, D. Babash, A. Kendzhasarova, R.Arzikulova

ENSURING FOOD SECURITY IN KAZAKHSTAN: THEORY, METHODOLOGY AND PRACTICE.

A. Nurtayeva, S. Aitkulova, A.Sadvakassova, A. Kurmantaeva

ANALYSIS OF THE EFFECTIVENESS OF THE RISK MANAGEMENT SYSTEM IN COMMERCIAL BANKS

Ramazanov A., C. Bazylhan

CONCEPTUAL BASIS OF HOSPITALITY.

Ramazanov A., Zh. Kuralov

ECONOMIC CHARACTERISTICS OF THE HOTEL BUSINESS

Torgaeva Sh.A

INTERNET MARKETING IN COMPANIES. 


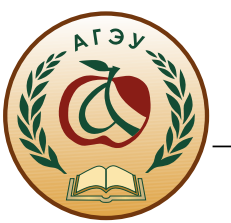

Статистика, учет и аудит, $\mathbf{4 ( 8 4 ) 2 0 2 2}$ стр. $22-34$

\author{
ГРНТИ 06.51.02 \\ УДК 338 \\ https://doi.org/10.51579/1563-2415.2022-1.04
}

\title{
DIGITALIZING TVET USING 4IR ELEMENTS
}

\author{
Norshymah Osman \\ Senior Assistant Director, Department of Skills Development, Putrajaya, Malaysia \\ e-mail: norshymah@gmail.com
}

\begin{abstract}
The border between the physical world and the cyber or digital world is becoming increasingly blurred. Lately, advancement in various technology especially in information and communication technology has led towards a digitalized era. This is supported by the betterment of communication infrastructure including the Internet which is widely accessible and affordable to the masses. On the other hand, the fourth industrial revolution does not only affect the industry but also influence various sectors including the education sectors. Unfortunately, with all the latest technologies, the Covid-19 pandemic still spread all over the world and affected the world's economy. The education sectors need to quickly adapt to this problem. New norms are being introduced to control the spreading of this virus which includes social distancing, avoiding crowded places and work from home. Digitalizing the education using Industry 4.0 elements could be a solution to continue to provide good quality education especially for TVET, now and in the future. This project is to develop an integrated online training management system for TVET in Malaysia as part of a fully integrated digital education system concept. MySPIKE is a training management system that was developed inhouse by the Department of Skill Development. Today, MySPIKE has integrated more than 21 modules and have more than 120 thousand users from students to teachers, training institutes, and industry players.
\end{abstract}

Keywords: Digitalization, TVET, 4IR, E-Government, Training Management System

Main provisions of the article. MySPIKE is part of the transformation toward a fully digitalized TVET education system. MySPIKE is a one-stop system for any service related to the Malaysian Skills Certification System. The system is accessible online using various devices and currently consists of 21 modules for various users. The system has successfully migrated the previously independent system, integrated and link new services and is already used to manage various aspects of the Malaysian Skills Certification.

Introduction. The beginning of the year 2020 has been devastating with the outbreak of the Covid-19 virus. As of July 2021, the virus has infected more than 205 million people all around the world, with a death toll of more than 4.3 million life [1]. Covid-19 is a pandemic caused by severe acute respiratory syndrome coronavirus 2 [2]. The virus usually spread from one person to another when in close contact with an infected person, often via small droplets emitted through coughing, sneezing, and talking [2]. The virus that started in China has affected various sectors such as manufacturing, services, the tourism sector and even the education sectors causing factories to be closed down and school to be cancelled. This has forced several countries into a lockdown including Malaysia [2]. Factories, business, schools, 


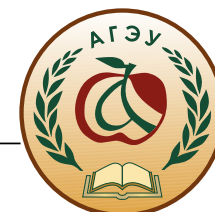

and various services including government services are being closed down to combat and stop the spreading of this small virus.

The fourth industry revolution (4IR) is currently in development [3] and is still not fully implemented. The slow implementation of 4IR, the lack of digitalization and interconnection have made it impossible to work from home. This have caused workers not able to work from home and forcing them to be given half paid wages or unpaid leaves or even worse losing their job. In the education sector, schools and training institutes are closed down and classes are done online. Because of the lack of preparation, infrastructure and suitable platform, educators are facing big challenges and some of the students are left behind. Education also involves various other aspects such as registration, grading, exams, program accreditation, and many other modules that support the learning and teaching processes. This is a big problem especially for Technical and Vocational Education Training (TVET) students that emphasize hands-on practical training [4]. In Malaysia, TVET is offered by public and private institutions. The public sector alone is governed by more than nine ministries and government bodies. This has caused a lot of misalignments.

After some month, most countries are taking the risk to soft start back their economy by opening various sectors in stages. Either way, this needs to be done with various restriction, creating a new norm which needs to be followed by everyone until everyone has been vaccinated. This new norm includes social distancing, avoiding crowded places and working from home. To adapt to this new norm, E-services needs to be strengthened and improved to provide online services to everyone including in the education sectors.

People need to adapt to this new norm using current and newly developed technologies. Since before the pandemic, various new technologies and advancement especially in the information and communication technology (ICT) sector have emerged causing various technological disruption and, in a way, changing our daily routine. The 4IR could not have come at a better time, introducing various new element. Today, people are dependent on technologies such as the Internet, and smartphones. This is happening because it is convenient and because the price of these technologies is more affordable. The advancements in ICT are supported by better infrastructures and various software development [5] such as the high-speed Internet, smartphones, large data centers and various intelligent software or applications [6]. With the widespread access to the Internet as a source of information and a communication tool, people and things all around the world are link and interconnected together. The advancement in computer technologies and software development have led towards the digitalization of the physical world. The synchronization between the physical world and the digital world is part of the fourth industrial revolution or Industry 4.0. New technological features such as the Internet of Things, augmented reality, big data and analytics, cloud computing, and cyber-security [7] compliments each other making the digital world reliable, resourceful and safe. ICT can be incorporated into the education sectors. With Internet connectivity, training providers will be interconnected and can share various resources and this is not just relevant during this pandemic period but also in the future.

The age of digitalization and the Internet have changed the way people run their daily routines. This includes the buying habits of consumers [7]; [3], information sourcing, the way people communicates and exchange data and the education sectors. E-commerce is getting the share of the market over conventional shopping [8] especially during movement control order in which people are restricted from going out [2]. In the education sectors, face to face classes is replaced by online learning through the Internet, using various platform. Home online learning and training system is suitable to avoid the crowded schools and institutes. Students 


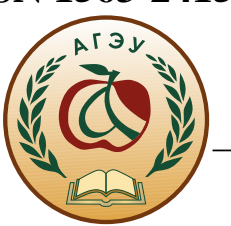

can also obtain education not just from the local providers but also from international colleges online. The only problem is that students especially TVET students cannot carry out hands-on practical lesson. With various changes and new alignment during this era, not just product can be customized, but also subject that can be learnt by students. Future jobs are no longer dependent on the traditional core program but by mix and matching various element needed for current sector and newly emerging sectors. Certain skillsets are needed in one industry whilst other skillsets are needed in other industry depending on how they are running their businesses.

A fully integrated and complete system is needed to provide good quality and effective education. The education sectors need to take advantage of various current and emerging 4IR technologies [9] and integrating ICT in all aspect of the education system from the learning and teaching process, the sharing of resources to the training management system. Digitalization of the education system is the way forward, especially as a preparation, should another pandemic hit the world again. Digitalizing the education will give more flexibility to students, teachers, training providers and all the stakeholder. An integrated education system can create a collaborative interaction between all the stakeholder [9], changing information and giving feedback that can then be used to improve the education system and also create borderless cooperation between institute all around the world.

In this project, a training management system is developed to integrate various element in training management such as registration, accreditation, grading, exams, syllabus and many more. The system is called MySPIKE and is developed internally by the Department of Skills Development under the Ministry of Human Resources. The system is aimed to be used to manage TVET training in Malaysia. The system that has been Online since 2019, is currently used to manage training related to the Malaysian Skills Certification System (SPKM). MySPIKE is one part of the fully digital education system concept. It is the stepping stone towards a fully digitalized education master plan.

Problem Statement. One of the main elements of a fully integrated digital education concept is the training management system which is focused on in this project. A training management system is really important to ensure systematic management of the education and learning process. Currently, most of the management part is done manually and locally. This involves many bureaucracies and mismanagement of data. With the current pandemic, some of the aspects are put on hold causing a lot of delays and interruption in the education system. Training management systems are normally only accessible locally and this is not convenient especially when students and staffs need to work from home.

In Malaysia, TVET is offered by public and private agencies. The public sector alone consists of at least nine different agencies. Most agencies running TVET programs has their training management system. The Department of Skills Development (JPK) which is responsible for skills training in Malaysian have their system. This is causing redundant leading to the waste of resources in which one must use too many systems to achieve the same goal.

Even within JPK itself, various systems and no integration are causing several functions to be overlapping with redundant data and redundant resources. In the age of information and data, various systems lead towards various database with no centralized database. Many data are redundant and taking up resources such as storage space. These data are also difficult to access by others creating a loophole in data generation that could lead to misinformation. Users need to login to several systems to achieve complete a task or goal.

Thus, the main objective of this project is to develop an online platform that integrates various elements, function, data and services related to the Malaysian Skills Certification Sys- 


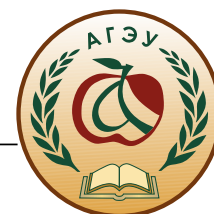

tem or TVET training in Malaysia. This includes establishing a database related to Skills Training for various stakeholder for their reference and data generation to assist in identifying the needs in the Department's planning and projection to strengthen the Malaysian Skills Certification System.

Significance. To stay relevant and be more sustainable in the future, the education sectors need to change the whole learning and teaching process by digitalizing the whole system and making it in line with the current industrial revolution [10]; [11]. The learning and teaching process and every aspect of it including the management of the learning and teaching process needs to continue even when people are lockdown during the current pandemic. Digitalizing education is not just relevant during this pandemic, but also in the future.

Digitalization is a national agenda. The Malaysian government have been pushing towards digitalization since 1995 with the introduction of E-government initiatives. It started with the introduction of websites for each ministry to today providing various online services which are accessible to all citizens anywhere at any time. On 19 February, Malaysia's Prime Minister Muhyiddin officially launched the MyDIGITAL initiative as part of the government's plans to "transform Malaysia into a digitally-driven, high-income nation and a regional leader in the digital economy" [12]. MyDIGITAL is designed to complement national development policies such as the Twelfth Malaysia Plan (RMKe-12), the 2030 Agenda for Sustainable Development and Wawasan Kemakmuran Bersama 2030 (WKB 2030) [12]. Among them, it includes ideas and plans to improve digital literacy, create high-income jobs, make banking and finance business easier and more organized, provide virtual educational access to our children and bring medical facilities to remote towns. Through this initiative, by 2025 , it is targeted that $80 \%$ of end-to-end online government services can be provided, $100 \%$ of the household will have internet access and all students have access to online learning. It is also projected that the digital economy will contribute $22.6 \%$ to the country's GDP, with plans to open up to 500,000 job opportunities in the digital economy [12]. Thrust one of the initiatives is to drive digital transformation in the public sector and thrust four of the initiative is to build agile and competent digital talent are part of the MyDIGITAL initiative that is relevant to the education sector. Thrust four especially is directly concerning the education sector and have a few strategies which are integrating digital skills into education at the primary and secondary level, shifting the focus of vocational and tertiary education from job-specific skills to competencies, the reskilling current workforce with the digital skills needed to stay relevant and ensure that gig workers are protected and equipped with the right skills [12]. As this is a national agenda, it is significant to explore the possibility of digitalizing the whole education system and this can be started from the training management system.

The other reason why this project is relevant is because of the current fourth industrial revolution (4IR). 4IR pillars consist of various elements which are related to ICT such as big data analytics, cyber-security, augmented reality, system integration, Internet of things, cloud computing, artificial intelligent, and blockchain [12]. The fundamental of 4IR is the CyberPhysical System (CPS) [7]; [13] and this involves digitalization. The main concept is connecting the physical world to a digital world and creating a digital copy [7]; [14] or in other words, digitalizing or virtualizing the physical world for example to create a digital twin that would mirror the physical world in real-time [15]; [16]; [17]. Industry 4.0 is also a national agenda. On 31 October 2018, the National Industry 4.0 Policy Framework was launched by the prime minister. This policy was published by the Ministry of International Trade and In- 


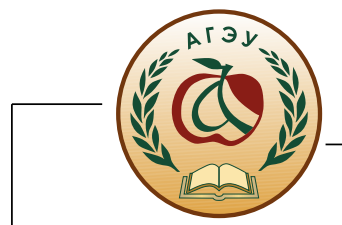

dustry (MITI) [7]. As for that, the education system needs to be in line with the current industrial revolution not just to educate people on 4IR but also to implement and adapt the 4IR element into the education system. Various elements of 4IR can be used as a tool in the learning and teaching process. For example, augmented reality can be used to teach students on a certain topic more realistically and this can be done online.

Today, various technology and advancement have open doors to endless possibilities. With the emergence of new technologies at a more affordable cost [18]; [19], various things that used to be impossible are emerging. This is supported by the largest network in the whole world which is the Internet. The Internet connects people [20]; [21] and has brought the world closer. Internet users are increasing exponentially and the number of devices connected to the Internet is increasing by the day [22]. The introduction of Internet Protocol Version 6 (IPv6) has enabled even more devices or things from computers to machines to various consumers devices to be connected to the Internet. The Internet has led to the disruption of our daily routine [22] with the introduction of various trends, for example, the trend of E-commerce [22]; [23] and E-learning. The use of social media such as Facebook and WhatsApp have also increased not just for socializing but also for E-commerce, E-learning and for spreading information. Internet-based companies such as Google, Facebook and Amazon are growing faster than ever since the last decade. With high demands on the Internet, communication infrastructures have been rapidly upgraded, including the introduction of 5G technology. This has made Internet speed increase and the coverage in widen. Now, most of the world is digitally interconnected with high-speed Internet [8]. The Internet subscription costs have also decreased making it available to the masses. As for that many new inventions, technology, and services related to the Internet have been introduced.

The outbreak of Covid-19, have caught the education systems off guard. Some training providers especially skills training institute are forced to shut down because they were not prepared for this pandemic. Digitalizing the education system is not something impossible if the relevant planning, resources and platform is established from the beginning and not adhoc as when the pandemic strike. Digitalizing the education system is not just relevant during a pandemic outbreak but must be a new norm for the future giving more flexibility to students, teachers, education manager and all the stakeholder. It is beneficial not just for the students but also for the teachers which are sometimes burdened with various training management aspects such as documentation.

Overall 4IR Digital Education Concept. 4IR is all about digitalization and interconnection for data exchange and data processing. This is called the Cyber-Physical System [7]. Physical systems are equipped with various IoT technologies for control and sensors for monitoring. This is part of the digitalization process. Then the system is interconnected and can be monitored and controlled locally or remotely. It is also connected to a cloud system that could provide various services.

Figure 1 shows the 4IR digital education concept. It consists of several elements such as the physical world, the cyber world, the cloud infrastructure, an artificial intelligent, and the interconnection of all these elements with all the stakeholder. 


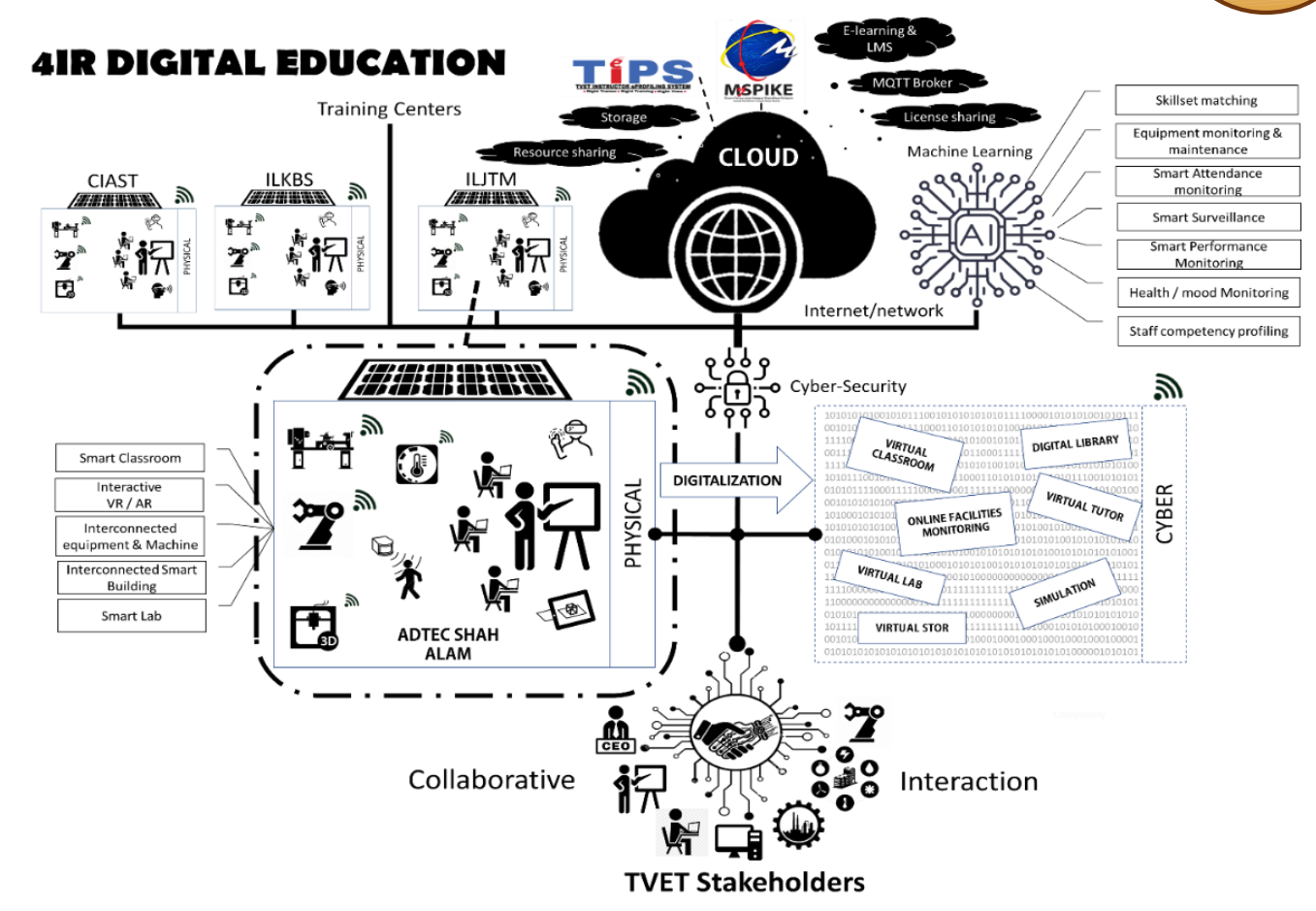

Figure 1. 4IR digital education concept

The first element is the physical world. This is the existing world in which traditional education operates. The current physical world needs to upgraded into an interconnected and smart environment. Machines and training equipment equipped with various monitoring sensors and are connected to the main network. The classrooms and labs are equipped with various smart system technology and connected to the internet. New training method is used for example virtual reality (VR) and augmented reality (AR). The whole physical system is also connected to a smart energy monitoring system for energy saving and to create a sustainable environment.

The physical system is then digitalized into a cyber world. In this cyber world, a digital twin can be created to mimic the existing physical machine and equipment which is available in the classrooms and labs. With this, students can still learn something even though they are not in a physical class or lab. This will allow each student to practice and use certain machine and equipment before using the real thing. Other than that, the digital twin will also be used to monitor the physical system in term of usage, maintenance and energy consumption. The digital world will also provide access to various online resources such as a digital library and self-online tutoring. In this way, the usage of paper is also reduced promoting a sustainable future. Another aspect of the digital world is the usage of simulation as part of the learning and teaching process. Students can use various simulation software to learn and understand the topic further. The simulation also provides a digital platform to carry out certain practical lesson and this can be done online. The digital world is accessible using a computer or any smart devices such as a smartphone.

The next element is the cloud infrastructure. The cloud act as the backbone connecting various system and interconnecting all the involved parties in the education system. The cloud infrastructure can provide various services such as storage, resources sharing such as notes 


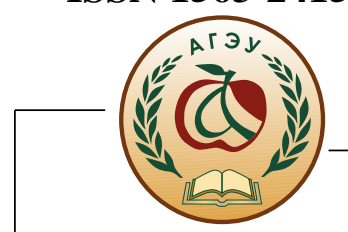

and research data, MQTT broker, and license sharing of various software and systems. The training management system is also stored in the cloud.

The next element is Artificial intelligent (AI). The AI can be used to analyze data, monitor the physical and digital world, receive feedback from all the stakeholder and help in various training management element. For example, the AI could monitor students and teacher's attendance, monitor the usage of machines, equipment and facilities, monitor the health and mood of students and teacher and suggesting various solutions for this matter and also monitor the performance of students and give suggestion on how to improve each student learning. The system can also survey the current job market trends and analyze feedback from the industry to determine which skill set is relevant to a student. It can also determine the training needed by a teacher to better improve their teaching skills.

The whole system is interconnected with each other. This includes the physical and digital world from one institute to all the other institutions that want to collaborate creating a big network. Various parties including the students, teachers, businesses, industries, training institute, facility management, machines, social media and all the stakeholder are interconnected to create an integrated network that opens door to a collaborative interaction with each other [24]. For example, a company can give feedbacks on an opening and this information can be conveyed to the correct person directly. Another example is the industry can request for a certain skill set to be added to the curriculum. The AI can determine and investigate this and determine whether this skillset is relevant. Is the concept of a fully integrated and smart digital education system.

MYSPIKE. The Malaysian Skills Integration Management System or simply MySPIKE is a centralized database system developed to improve the delivery and management system of the Malaysian Skills Certification System. It is a training management system that is part of the 4IR digital education concept. MySPIKE was first used in 2019. It was officially launched on 19 August 2020 by the Minister of Human Resource. MySPIKE was registered as a trademark and has acquired Copyright from the Intellectual Property Corporation of Malaysia (MyIPO) under the Copyright Act 1987 on 25 August 2020.

Initially, it consisted of four main modules which are Program Accreditation Modules, Student Registration, Personnel Certification, Verification and Non-Credit Assessment. Then several other modules are added which are Accreditation and Verification function that meets the Competency-Based Credit Assessment (CU) and the Module-Based Credit Assessment. MySPIKE continues to expand its functionality to fully support SPKM with the addition of National Occupational Skills Standard (NOSS) Modules, Star Rating, Malaysian Skills, Prior Performance Assessment (PPT) and Online Payment. The functionality of MySPIKE has currently been improved in compliance with the Code of Practice for TVET Program Accreditation (COPTPA), KAPPK and the 652 Act.

Objective. The main objective of this project is to develop an integrated online platform that integrates all data regarding the Malaysian Skills Certification System. Other than that, the objective is to establish a database related to Skills Training for stakeholder reference and to assist in identifying the needs and insight in the JPK's planning and projection to strengthening the Malaysian Skills Certification System.

Existing systems will be migrated into MySPIKE. New modules are developed to includes all services offered by JPK. New services and link with other government agencies is also developed and integrated into MySPIKE. Figure 2 shows the integration and migration of various modules. 


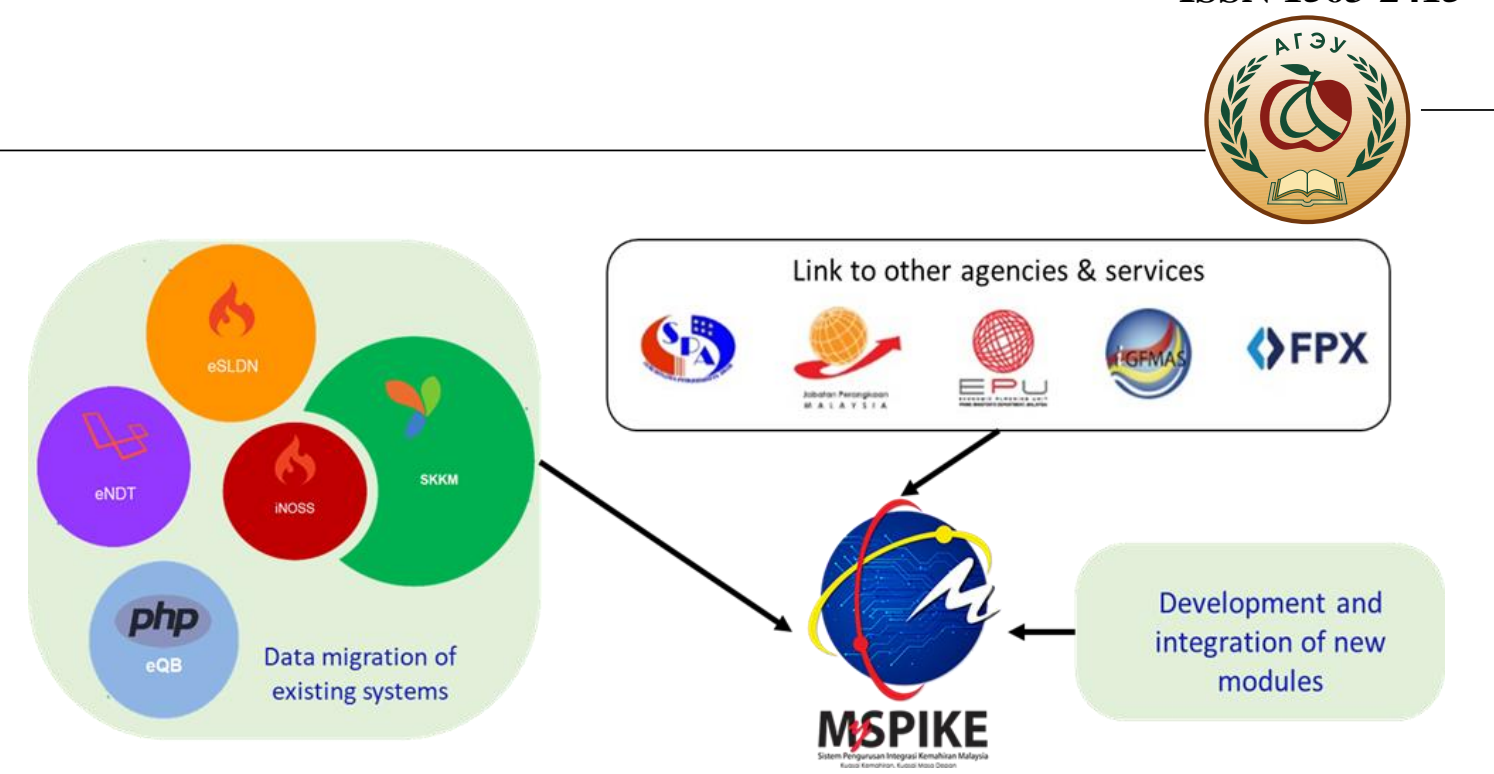

Figure 2. Data migration and integration of new services

Development. MySPIKE was developed internally by JPK's staffs. It uses rapid application development (RAD) as shown in Figure 3.

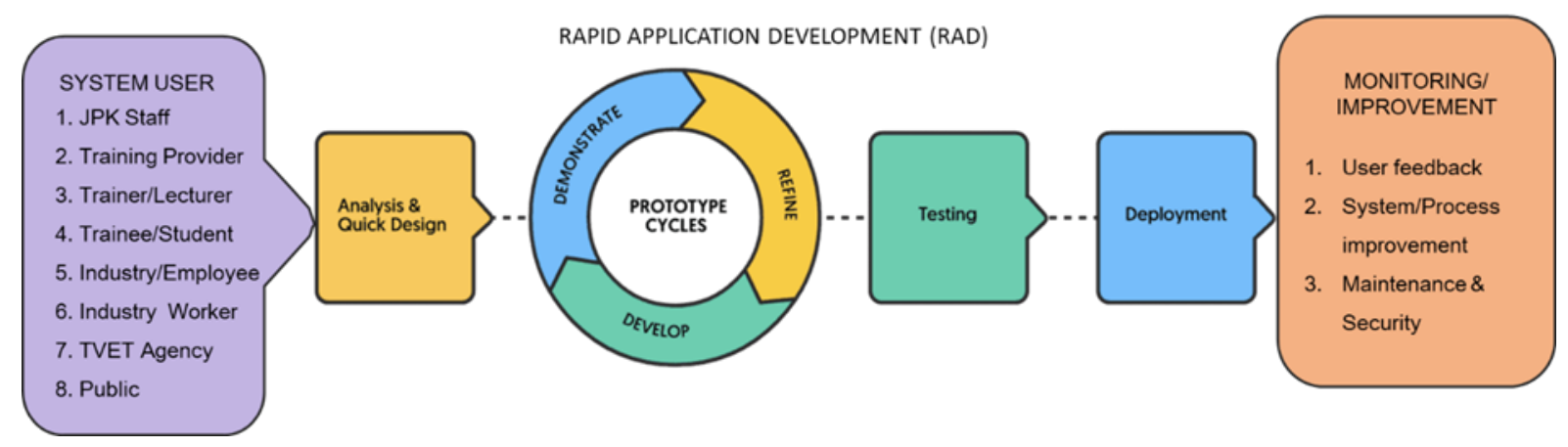

Figure 3. The development process of MySPIKE

MySPIKE currently consists of 21 modules and is expanding. Among the currently established modules are Users, Personnel, Accreditation, Verify, Registration, Accreditation of Prior Achievement (PPT), Assessment, Certification, NOSS, Star Ratings, SkillsMalaysia, Industry, ePayment, eQB (question bank), eWIM (written information material), Statistics, Financing, Executive, Complaints, Problem Complaint Form and eSLDN (Sistem Latihan Dual National). Each of these modules has its function and is accessible using only one single login. Therefore, a user just needs to have a single login for all the function of SPKM. Figure 4 shows MySPIKE modules. 


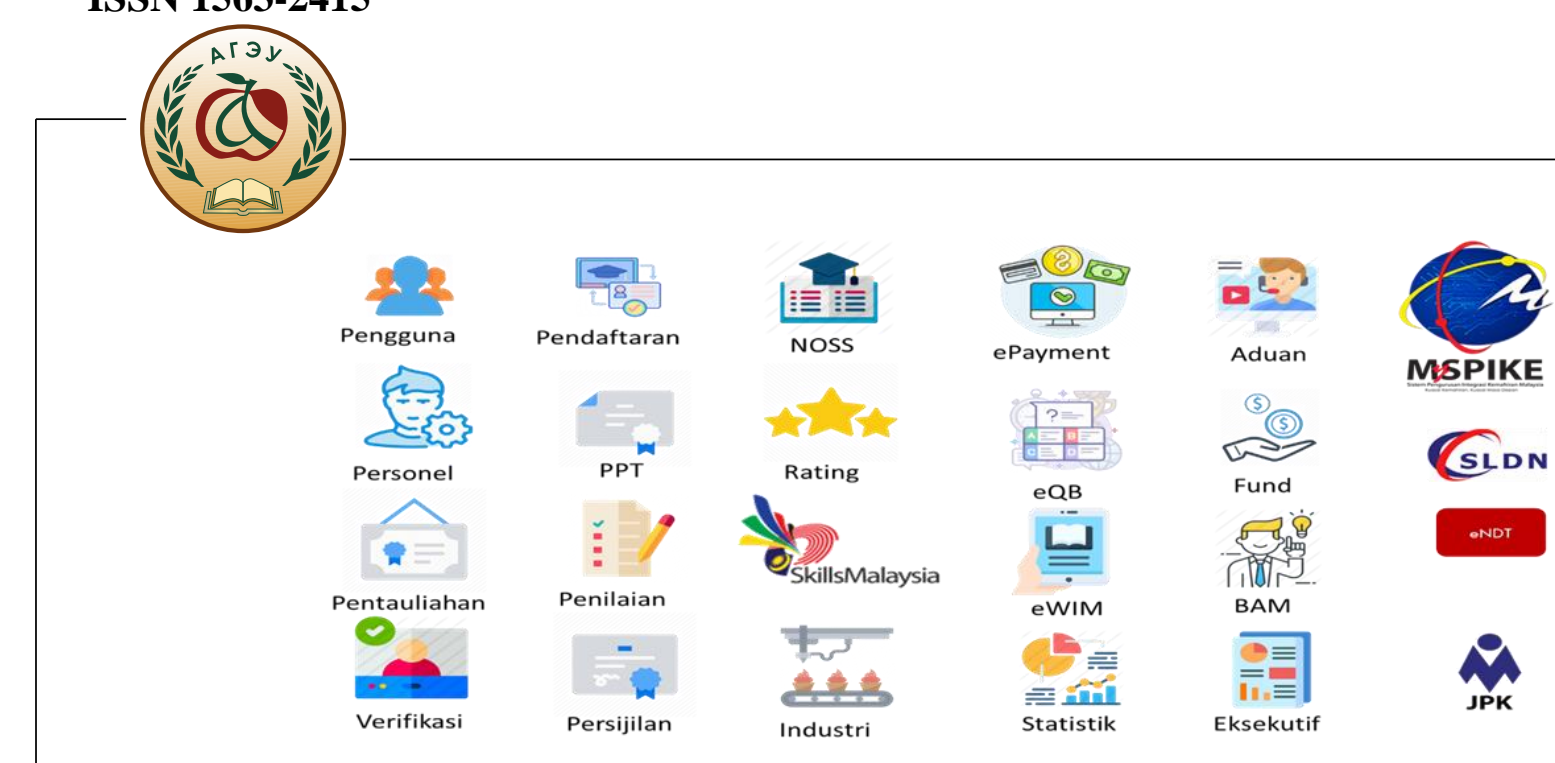

Figure 4. MySPIKE Modules

Network Infrastructure. Figure 5 shows the network infrastructure of MySPIKE. It is hosted by MAMPU and uses the MariaDB database.

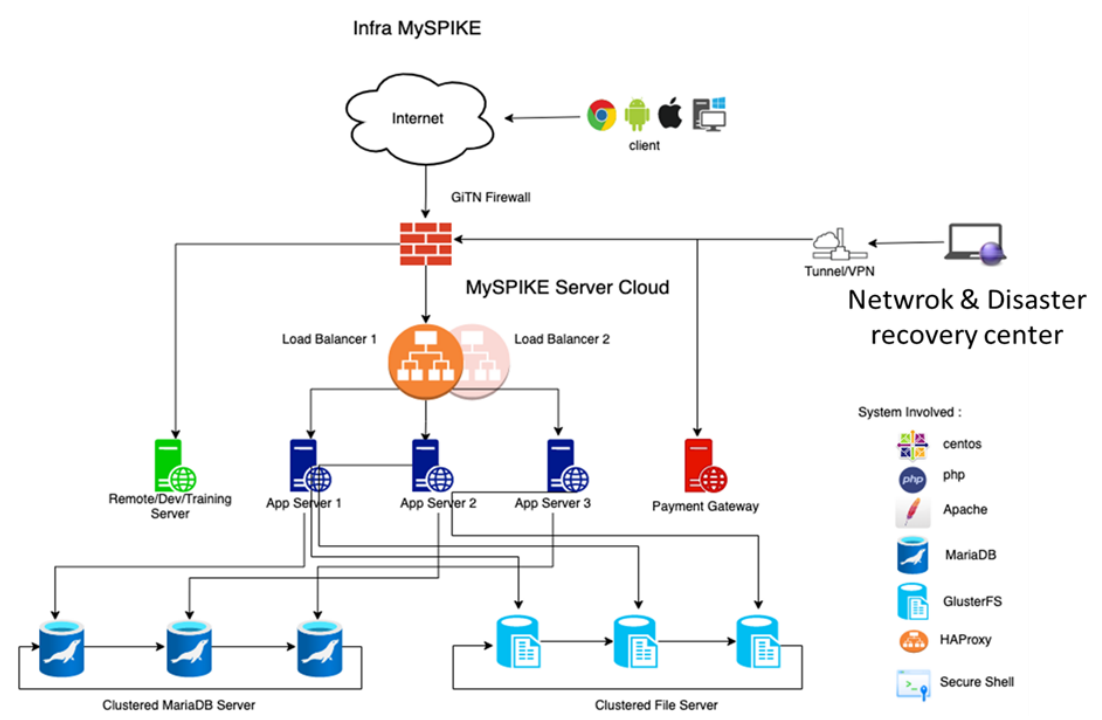

Figure 2. MySPIKE Network Infrastructure

Statistics. Currently, MySPIKE has had 126,081 registered users since July 2018. It can be used by anyone interested and involved in TVET comprising of individuals, instructor, TVET training providers, employees and industry practitioners as well as employers. Currently, there are 1,387 training providers registered in the system.

Benefit and Impact. MySPIKE is a fully integrated system. MySPIKE integrates and migrates previously existing system into a single centralized system and this has eliminated redundancies in work and help simplify the process flow. It provides fast and wide access for users and is accessible from various devices. This helps reduce several bureaucracies making various services faster. With integrated online payment, a transaction can be made easily, safely and efficiently.

MySPIKE was developed in-house. This has reduced development cost. This has also reduced dependency on outsourcing contractors by utilizing in-house expertise and resources, 


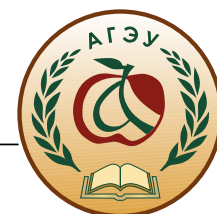

thus grooming existing talent in the government sector. It is also to respond to the government's call to develop and groom "Digital Transformers" in civil servants with highly skilled comprising technical experts and professional ICT-related talent and in line with the transformation to e-Government, in which government officer needs to be digital literate.

With a centralized system, data generation is more centralized. This will provide useful information and insight. Thus, a big data database can be established and a comprehensive skills training insight is made available and accessible to all the stakeholder. MySPIKE uses MAMPU cloud servers, thus the database is protected to ensure the privacy of users and backup at the Disaster Recovery Center (DRC). This ensures the integrity of the data.

MySPIKE is an online system thus promoting green technology towards a sustainable ecosystem. This promotes paperless service, reduce operation cost and simplify process flow whilst enhance productivity.

Further Development. The rebranding of MySPIKE in 2020 has open various possibility. It is targeted to be part of the bigger 4IR digital education concept. It is targeted in the future to be the Big Data for TVET, integrating various function and data from TVET Student and Instructor across various Agencies. Various modules will be added as needed in the future.

Conclusion. Digitalization is very important today. The world was caught off guard with the COVID-19 pandemic which has forced the world to a standstill. This has further highlighted the importance of digitalization. The current fourth Industrial revolution has provided various tools for a digitalize ecosystem. The education system which is important to produce a quality workforce for the nation's economy needs to be able to function in all situation. Thus, digitalization in the education sector is very important and this can be done using 4IR elements.

MySPIKE is part of the transformation toward a fully digitalized TVET education system. MySPIKE is a one-stop system for any service related to the Malaysian Skills Certification System. The system is accessible online using various devices and currently consists of 21 modules for various users. The system has successfully migrated the previously independent system, integrated and link new services and is already used to manage various aspects of the Malaysian Skills Certification.

Acknowledgement. The authors would like to express their gratitude to JPK and the Ministry of Human Resources for supporting this project.

\section{References}

1 Worldometer. (2021). COVID-19 CORONAVIRUS PANDEMIC. Retrieved March 20, 2021, from https://www.worldometers.info/coronavirus/

2 Elengoe, A. (2020). COVID-19 Outbreak in Malaysia. Osong Public Health and Research Perspectives, 11(3), 93-100. https://doi.org/https://doi.org/10.24171/j.phrp.2020.11.3.08

3 Roblek, V., Meško, M., \& Krapež, A. (2016). A Complex View of Industry 4.0. SAGE Open, 6(2), 1-11. https://doi.org/10.1177/2158244016653987

4 Wahab, A. R., \& Saud, M. S. (2021). Pembangunan Instrumen Karakter Kreatif Pelajar Pendidikan Teknikal Dan Latihan Vokasional (TVET). ANP Journal of Social Science and Humanities, 2(2), 112-122. https://doi.org/10.53797/anp.jssh.v2i2.16.2021

5 Wang, S., Wan, J., Li, D., \& Zhang, C. (2015). Implementing Smart Factory of Industrie 4.0 : An Outlook. International Journal of Distributed Sensor Networks, 2016, 10. https://doi.org/10.1155/2016/3159805 


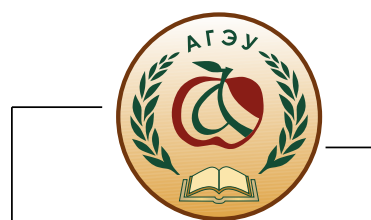

6 Crnjac, M., Veža, I., \& Banduka, N. (2017). From concept to the introduction of industry 4.0. International Journal of Industrial Engineering and Management, 8(1), 21-30.

7 Malaysia Ministry of International Trade and Industry. (2018). Industry 4WRD: NATIONAL POLICY ON INDUSTRY 4.0. Perpustakaan Negara Malaysia. Retrieved from http://www.miti.gov.my/index.php/pages/view/2047?mid=29

8 Raman, A., \& Annamalai, V. (2011). Web services and e-shopping decisions: A study on malaysian e-consumer. IJCA Special Issue, ("Wireless Information Networks \& Business Information System"), 54-60. https://doi.org/10.1111/conl.12116

9 ILO-UNESCO. (2020). The Digitization of TVET and Skills Systems (English Ed). Geneva: Document and Publications Productions Printing en Distribution Branch (PRODOC). Retrieved from https://www.ilo.org/skills/areas/skills-policies-andsystems/WCMS 752213/lang--en/index.htm

10 Arlinwibowo, J., Retnawati, H., \& Kartowagiran, B. (2021). How to Integrate STEM Education in Indonesian Curriculum? A Systematic Review. Challenges of Science. Issue IV, 2021, pp. 18-25. https://doi.org/10.31643/2021.03

11 Kenzhaliyev, B. K., Imangalieva, L. M., Manapova, A. I., Azlan, M. N. (2021). Kaolinite clays as a source of raw materials for the aluminum industry of the Republic of Kazakhstan. Kompleksnoe Ispol'zovanie Mineral'nogo Syr'a = Complex Use of Mineral Resources. 4(319), pp. 5-12. https://doi.org/10.31643/2021/6445.34 BLUEPRINT.

12 Economic Planning Unit. (2021). MALAYSIA DIGITAL ECONOMY

13 Zhong, R. Y., Xu, X., Klotz, E., \& Newman, S. T. (2017). Intelligent Manufacturing in the Context of Industry 4.0: A Review. Engineering, 3(5), 616-630. https://doi.org/10.1016/J.ENG.2017.05.015

14 Sanders, A., Sanders, A., Elangeswaran, C., \& Wulfsberg, J. (2016). Industry 4.0 Implies Lean Manufacturing: Research activities in industry 4.0 function as enablers for lean manufacturing. Journal of Industrial Engineering and Management, 9(3), 811-833. https://doi.org/10.3926/jiem.1940

15 Lee, J., Kao, H. A., \& Yang, S. (2014). Service innovation and smart analytics for Industry 4.0 and big data environment. Procedia CIRP, 16(Product Services Systems and Value Creation. Proceedings of the 6th CIRP Conference on Industrial Product-Service Systems, 3-8. https://doi.org/10.1016/j.procir.2014.02.001

16 Mohammed, Z. K. A., \& Sayed Ali Ahmed, E. (2017). Internet of Things Applications, Challenges and Related Future Technologies Internet of Things Applications , Challenges and Related Future Technologies. World Scientific News, 67(February), 126-148. https://doi.org/10.1016/j.respol.2006.05.004

17 Schmidt, R., Möhring, M., Härting, R.-C., Reichstein, C., Neumaier, P., \& Jozinović, P. (2015). Industry 4.0 - Potentials for Creating Smart Products: Empirical Research Results. In Business Information Systems: 18th International Conference, BIS 2015. (Vol. 208, pp. 16-27). Springer International Publishing. https://doi.org/10.1007/978-3-319$\underline{19027-3}$

18 MacDougall, W. (2013). Industrie 4.0: Smart Manufacturing for the Future. (J. Hull \& S. Sasse, Eds.), Germany Trade and Invest. Germany Trade and Invest. https://doi.org/10.1007/978-3-642-36917-9

19 Thoben, K., Wiesner, S., \& Wuest, T. (2017). "Industrie 4.0" and Smart Manufacturing - A Review of Research Issues and Application Examples. International Journal of Automation Technology, 11(1), 4-16. https://doi.org/10.20965/ijat.2017.p0004 


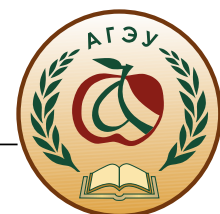

20 Enke, J., Kraft, K., \& Metternich, J. (2015). Competency-oriented design of learning modules. Procedia CIRP, 32 (The 5th Conference on Learning Factories 2015 Competency-oriented), 7-12. https://doi.org/10.1016/j.procir.2015.02.211

21 Weyer, S., Schmitt, M., Ohmer, M., \& Gorecky, D. (2015). Towards Industry 4.0 Standardization as the crucial challenge for highly modular, multi-vendor production systems. IFAC-PapersOnLine, 48(3), 579-584. https://doi.org/10.1016/j.ifacol.2015.06.143

22 Godoy, A. J. C., \& Pérez, I. G. (2018). Integration of Sensor and Actuator Networks and the SCADA System to Promote the Migration of the Legacy Flexible Manufacturing System towards the. Journal of Sensor and Actuator Networks, 7(23). https://doi.org/10.3390/jsan7020023

23 Mittag, T., Gausemeier, J., Graessler, I., Iwanek, P., Koechling, D., \& Petersen, M. (2014). Conceptual design of a self-optimising production control system. Procedia CIRP, 25(8th International Conference on Digital Enterprise Technology-DET 2014 - "Disruptive Innovation in Manufacturing Engineering towards the 4th Industrial Revolution), 230-237. https://doi.org/10.1016/j.procir.2014.10.033

24 Drath, R., \& Horch, A. (2014). Industrie 4.0: Hit or Hype? IEEE Industrial ElEctronIcs MagazInE, (june), 56-58.

\title{
ОЦИФРОВКА ТVЕТ С ИСПОЛЬЗОВАНИЕМ ЭЛЕМЕНТОВ 4IR
}

\author{
Норшымах Осман \\ Департамент повышения квалификаџии, Путраджайя, Малайзия \\ e-mail:norshymah@gmail.com
}

\begin{abstract}
Аннотация: Граница между физическим миром и кибер- или цчифровым миром становится все более размытой. В последнее время прогресс в различных технологиях, особенно в области информационных и коммуникационных технологий, привел к ичифровой эпохе. Этому способствует совершенствование коммуникационной инфраструктуры, в том числе широкодоступного и недорогостоящего для широких масс Интернета. С другой стороны, четвертая промышленная революция влияет не только на промышленность, но и на различные сектора, включая сектор образования. К сожалению, при всех новейших технологиях пандемия Covid-19 все же распространилась по всему миру и затронула мировую экономику. Секторы образования должны быстро адаптироваться к этой проблеме. Вводятся новые нормы для контроля за распространением этого вируса, которые включают социальное дистанцирование, избегание людных мест и работу из дома. Цифровизачия образования с использованием элементов Индустрии 4.0 может стать решением для продолжения предоставления качественного образования, особенно для ТПОП, сейчас и в будущем. Этот проект направлен на разработку интегрированной системы управления онлайн-обучением для ТПОП в Малайзии в рамках концепџии полностью интегрированной системы цииррового образования. MySPIKE - это система управления обучением, разработанная Департаментом развития навыков. Сегодня MySPIKE объединяет более 21 модуля и насчитывает более 120 тысяч пользователей, от студентов до преподавателей, учебных заведений и представителей отрасли.
\end{abstract}

Ключевые слова: ичифровизаџия, ТПОП, 4IR, электронное правительство, система управления обучением. 


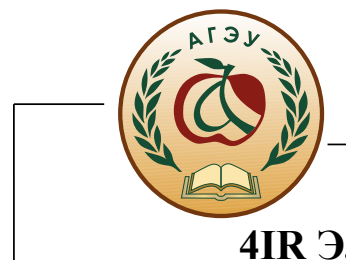

\title{
4IR ЭЛЕМЕНТТЕРІН ҚОЛДАНУ АРҚЫЛЫ ТЖКБ ЦИФРЛАНДЫРУ
}

\author{
Норшымах Осман \\ Жетілдірілген зерттеулер бөлімі, Путраджая, Малайзия \\ e-mail:norshymah@gmail.com
}

Аннотация: Физикалық әлем мен кибер немесе ичифрлық әлем арасындавы шекара барван сайын бұльццвырлануда. Соңъъы уақытта әртүрлі технологиялардың, әсіресе ақпараттық-коммуникациялық технологиялар саласындагы жетістіктер uүифрльққ дәуірге әкелді. Бұван коммуникачияльққ инфрақұрылымды, соның імінде кең

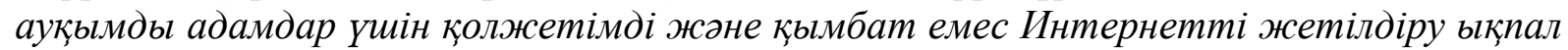
етеді. Екінші жавынан, төртінші өнеркасіптік революция тек өнеркәсіпке вана емес, сонымен қъатар әртүрлі салаларва, соның ішінде білім беру саласына да әсер етеді. Өкінішке орай, барльқ соңъы технологиялармен Ковид-19 пандемиясы сован қарамастан бүкіл әлемге таралып, жаһандық экономикава әсер етті.

Білім беру саласы бұл мәселеге тез бейімделуі керек. Бұл вирустың таралуын бақылау үшін әлеуметтік қ̧ашықтықты, адам көп жиналатын орындардан аулақ болуды және үйден жұмыс істеуді құмттитын жаңза нормалар енгізілуде. Индустрия 4.0 элементтерін пайдалана отырып, білім беруді ијифрландыру қ̧азіргі уақыытта және болашақта, әсіресе ТжКБ үшін сапалы білім беруді жалгастыру шешімі бола алады. Бұл жоба тольвымен интеграчияланван ичиррльқ білім беру жүйесі тұжырымдамасының бөлігі ретінде Малайзияда ТжКБ үшін интеграцияланван онлайн оқытуды басқару жүйесін әзірлеуге бавытталван. МуSPIKE - давдыларды дамыту бөлімі әзірлеген оқытуды басқ̧ару жүйесі. Бүгінгі күні MySPIKE-де 21-ден астам модуль және 120 000-нан астам пайдаланушылар бар, олар студенттерден тәрбиешілерге, оку орындары мен сала өкілдеріне дейін. жүйесі.

Түйін сөздер: иифрландыру, ТжКБ, 4IR, электронды Үкімет, оқытудыь басқару

Author information

Norshymah Osman - Senior Assistant Director, Department of Skills Development, Putrajaya, Malaysia,Email: norshymah@gmail.com

Автор туралы ақпарат

Норшымах Осман - Давдыларды дамыту департаменті директорының ава көмекшісі, Путраджайя, Малайзия, Электрондық nошта: norshymah@gmail.com

Информация об авторе

Норшима Осман - старший помощник директора Департамента развития навыков, Путраджайя, Малайзия, электронная почта: norshymah@gmail.com 


\section{ПРАВИЛА ДЛЯ АВТОРОВ ЖУРНАЛА}

(с учетом изменений в Требованиях к научным изданиям для включения их в Перечень изданий, рекомендуемых для публикации результатов научной деятельности-Приказ Министра образования и науки Республики Казахстан от 30 апреля 2020 года № 170)

Журнал «Статистика, учет и аудит» (в дальнейшем - Журнал) публикует оригинальные работы ученых и специалистов научно-исследовательских организаций, высших учебных заведений, организаций и административных структур Казахстана, а также иностранных авторов. В журнале публикуются оригинальные статьи по научным направлениям статистики, учета и аудита, микро и макроэкономические вопросы международной и отечественной экономики, финансов, информатики и педагогики. Также публикуются рецензии, хроники научной жизни и др. материалы, имеющие отношение к деятельности Учредителя журнала.

Обязательными условиями для публикации являются:

1.Соответствие публикуемых научных статей (в том числе обзоров) заявленной цели и тематическому направлению журнала. Научная статья - изложение собственных выводов и промежуточных или окончательных результатов научного исследования, экспериментальной или аналитической деятельности, содержащее авторские разработки, выводы, рекомендаций ранее не опубликованные и обладающие новизной; или посвященное рассмотрению ранее опубликованных научных статей, связанных общей темой (систематический обзор).

2.Структура научной статьи включает название, аннотацию, ключевые слова, основные положения, введение, материаль и методы, результаты, обсуждение, заключение, информацию о финансировании (при наличии), список литературы. В каждой оригинальной статье (за исключением социально-гуманитарного направления) обеспечивается воспроизводимость результатов исследования, описывается методология исследования с указанием происхождения оборудования и материалов, методов статистической обработки данных и других способов обеспечения воспроизводимости. Содержание других типов публикаций не превышает 10\% (десять) от общего количества статей в номере. При этом автор или коллектив авторов вносят значительный вклад в концепцию, научный дизайн, исполнение или интерпретацию заявленного научного исследования и создание научной статьи. Наличие библиографической информации - заголовка статьи, аннотации, ключевых слов, информации об авторах на английском языке обязательно.

2.1 В аннотации (аңдатпа, abstract) публикуемой статьи на языке статьи излагаются суть и использованные методы исследования, суммируются наиболее важные результаты и их значимость. Объем аннотации составляет не более 300 слов (минимальный объем-100 слов). 


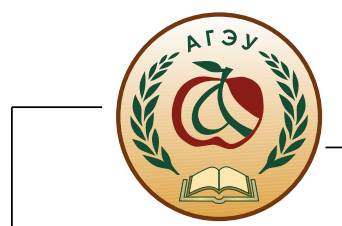

2.2 Резюме (түйін, summary) на двух не на языке статьи (казахском, русском и английском) языках. Например, резюме и summary- это не переводы аңдатпа, а краткое изложение о статье на русском и английском языках (если статья написана на казахском) и рекомендуется их приводить после списка литературы.

2.3 Ключевые слова (түйінді сөздер, key words) предназначены для поиска текста статьи и определения ее предметной области. Например, они приводятся после аннотации (если статья написана на русском) и двух резюме (түйін, summary). Ключевые слова должны обеспечить наиболее полное раскрытие содержания статьи.

2.4 Информация об авторах - имена (Фамилия И.О. авторов), аффилиации (полное название учреждения, которое представляет автор (авторы), название страны, и адреса всех авторов публикаций, в том числе с указанием основного автора-выделить звездочкой (*), е-таil (основного автора).

3. Список литературы. Ссылки на источники в тексте статьи даются только в квадратных скобках (без цитирования [12], при цитировании или пересказе авторского текста [12, с. 29]). Используемая литература, указываемая в ссылках, дается в конце статьи пронумерованной и в порядке упоминания по авторам. Архивные материалы в список не включаются, ссылки на них помещаются в тексте в круглых скобках. При использовании в статье: источников законодательных, нормативно-правовых актовссылки на них делать в тексте сразу же после них, а источников из электронных ресурсов или удаленного доступа (Интернета) в списке литературы приводится библиографическая запись источника и ссылка на сетевой ресурс с полным сетевым адресом в Интернете. Желательно указывать дату обращения к ресурсу. Список литературы предоставляется на языке оригинала и должен состоять не более чем из 20 наименований.

3.1 Наличие транслитерированных списков литературы (используемых источников) к каждой статье. Существуют различные системы транслитераций. Предложение редакции по транслитерации (вы имеете право найти другой способ):

3.1. На данной странице Вы можете выполнить транслит - онлайн русских букв латиницей:

Транслитерация с русского на английский онлайн

https://lim-english.com/posts/transliteratsiya-s-russkogo-na-angliiskij/

4. Ответственность за содержание статей несут авторы.

5. Этические принципы, которыми должен руководствоваться автор научной публикации. Представление статьи на рассмотрение в редакцию подразумевает, что она содержит полученные автором (коллективом авторов) новые научные результаты, которые ранее нигде не публиковались. Автор должен осознавать, что несет персональную ответственность за представляемый текст рукописи. Это предполагает соблюдение следующих принципов:

5.1. Автор статьи гарантирует, что предоставляет редакции журнала достоверные результаты выполненной научной работы или исследования. Заведомо ложные или 
сфальсифицированные утверждения приравниваются к неэтичному поведению и являются неприемлемыми.

5.2. В случае, если главный редактор журнала запрашивает у автора научной статьи ее исходные данные для рецензирования, автор, если это возможно, должен быть готов предоставить открытый доступ к таким данным; автор также берет на себя обязательство сохранять исходные материалы статьи в течение разумного периода, прошедшего после ее публикации.

5.3. Автор гарантирует, что результаты исследования, изложенные в рукописи, представляют собой самостоятельную и оригинальную работу. В случае использования фрагментов чужих работ или заимствования утверждений других авторов, в статье должны быть оформлены соответствующие библиографические ссылки с обязательным указанием автора и первоисточника. Все статьи проходят обязательную проверку через систему «Антиплагиат». Все статьи проверяются на предмет обнаружения плагиата (оригинальность должна быть не менее 70\%). Применяется лицензионная программа АНТИПЛАГИАТ.ВУЗ Договор № 1065 от 29 декабря 2020 г.) Чрезмерные заимствования, а также плагиат в любых формах, включая неоформленные цитаты, перефразирование или присвоение прав на результаты чужих исследований, являются неэтичными и неприемлемыми действиями. Статьи, представляющие собой компиляции из материалов, ранее опубликованных другими авторами, без их творческой переработки и собственного авторского осмысления, редакцией журнала к публикации не принимаются.

5.4. Автор безусловно признает вклад всех лиц, так или иначе повлиявших на ход исследования или определивших характер представленной научной работы. В частности, в статье должны быть сделаны библиографические ссылки на отечественные и зарубежные публикации, которые имели значение при проведении исследования. Информация, полученная в частном порядке путем разговора, переписки или обсуждения с третьими лицами, не должна использоваться без получения открытого письменного разрешения от ее источника. Все источники должны быть раскрыты. Даже в том случае, если используемые в статье письменные или иллюстративные материалы получены от большого числа людей, автору статьи необходимо представить в редакцию все соответствующие разрешения на использование этих материалов.

5.5. Автор гарантирует, что представленная в журнал рукопись статьи не находится на рассмотрении редакции другого научного журнала и не была ранее опубликована в другом журнале. Несоблюдение этого принципа расценивается как грубое нарушение этики публикаций и дает основание для снятия статьи с рецензирования. Текст статьи должен быть оригинальным, то есть публиковаться в представленном виде в периодическом печатном издании впервые. Если элементы рукописи ранее были опубликованы в другой статье, автор обязан сослаться на более раннюю работу и указать, в чем состоит существенное отличие новой работы от предыдущей. Дословное копирование собственных работ и их перефразирование неприемлемы, они могут быть использованы только как основа для новых выводов. 


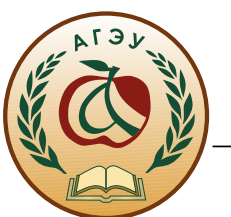

5.6. Автор статьи гарантирует правильность списка соавторов. В числе соавторов должны быть указаны все лица, внесшие существенный интеллектуальный вклад в концепцию, структуру, а также в проведение или интерпретацию результатов представленной работы. Другим лицам, чье участие в представленной в журнал работе ограничилось некоторыми ее аспектами, должна быть выражена благодарность. Автор статьи должен также гарантировать, что все соавторы ознакомлены с окончательным вариантом статьи, одобрили его и согласны с ее представлением к публикации. Все указанные в статье соавторы несут совокупную ответственность за ее содержание. Если статья является мультидисциплинарной работой, соавторы могут также принимать на себя ответственность за свой личный вклад в работу, продолжая при этом нести коллективную ответственность за результат исследования в целом. Недопустимо указание в качестве соавторов статьи лиц, не принимавших участия в исследовании.

5.7. В случае обнаружения существенных ошибок или неточностей в статье на этапе ее рассмотрения или после ее опубликования автор обязан незамедлительно уведомить об этом редакцию журнала и принять совместное решение о признании ошибки и/или ее исправлении в максимально короткие сроки. Если редакция узнает от третьего лица, что опубликованная работа содержит существенные ошибки, автор обязан незамедлительно исправить их либо предоставить редакции доказательства правильности ранее предоставленной им информации.

5.8. Автор обязуется указывать в своих рукописях все источники финансирования работы, заявлять о возможных конфликтах интересов, которые могут повлиять на результаты исследования, их интерпретацию, а также на суждения рецензентов. Потенциальные конфликты интересов должны быть раскрыты как можно раньше.

6. Поступившие от авторов научные статьи проходят первичный контроль на комплектность и правильность оформления. Далее статья направляется на предмет обнаружения плагиата (оригинальность должна быть не менее 70\%). Применяется лицензионная программа АНТИПЛАГИАТ.ВУЗ Договор № 1065 от 29 декабря 2020 г.), после чего, научные статьи, поступившие в редакцию, проходят обязательное слепое рецензирование порядок прохождения, которых описан в разделе Рецензирование.

При отрицательном отзыве рецензентов редакция Журнала обязуется сообщать авторам все комментарии об их работе, сделанные рецензентами, если только они не содержат обидные или клеветнические замечания.

7. В конце статьи предоставляются заполненные формы для размещения сборника статей в Научной электронной библиотеке (eLibrary.ru) и включения сборника статей в Российский индекс научного цитирования (РИНЦ):

\section{ФОРМА}

для размещения сборника статей в Научной электронной библиотеке (eLibrary.ru) и включения сборника статей в Российский индекс научного цитирования (РИНЦ)

1. Название статьи: на казахском, русском и английском языках 
2. Сведения об авторе (авторах):

- фамилия, имя, отчество (полностью) автора (авторов) с указанием ученой степени и ученого звания (при наличии) на трех языках:

- место работы автора (авторов) (должность и организация) на трех языках:

- контактная информация:

e-mail автора (авторов) - тел.номер автора (авторов) -

8. Редакция оставляет за собой право редакторской правки.

Технические требования

1. Общий объем статьи, включая аннотацию, ключевые слова, литературу, таблицы и рисунки не должен превышать 6-8 страниц. Исключение составляют заказные и обзорные статьи.

2. Статьи должны быть оформлены в строгом соответствии шрифтом гарнитуры Times New Roman.

МРНТИ

\section{Схематический пример оформления статьи}

УДК 339.74

DOI (Digital Object Identifier) xxxxxxxxxx

По центру приводятся: Название статьи

(Поля: сверху - 2 см., слева-3 см., справа -1,5 см. Шрифт полужирный. Кегль-14 пт, межстрочный интервал - одинарный.)

Фамилии и инициалы авторов (напр.И.В.Иванов, Ю.П.Крылов)

Полное название учреждения, которое представляе(ю)т автор(ы) с указанием города и страны, электронного адреса основного автора выделением надстрочной звездочкой. Если авторы из разных учреждений, то соответствие между автором и учреждением устанавливается надстрочными индексами, например:

\section{${ }^{*}$ И.В. Иванов ${ }^{1}$, Ю.П. Крылов ${ }^{2}$}

${ }^{1}$ Алматинский гуманитарно-экономический университет, Алматы, Казахстан 2 Международная академия бизнеса, Алматы, Казахстан e-mail: ivanov@mail.ru

- Аннотация.

- Ключевые слова.

- Текст статьи: Поля: сверху, снизу - 2 см., слева - 3 см., справа -1,5 см. Шрифт Times New Roman. Кегль-14 пт. Абзацный отступ-1,25 см., межстрочный интервал одинарный).

- Список литературы. Транслитерированный список литературы (References)

- После списка литературы приводятся:

Название статьи перед каждым резюме на двух не на языке статьи (казахском, русском и английском) языках. 
ISSN 1563-2415

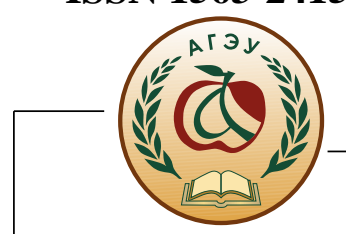

После каждого названия статьи приводятся см. выше (последовательно) пп. 2.4, 2.2, 2.3 Руководства для авторов

3. Таблицы и рисунки с названиями должны быть пронумерованы по порядку (если их несколько). Нумерация таблицы (Таблица 1.) должна быть расположена вверху слева выше названия таблицы через абзацный отступ.

4. Рисунки, фотографии, таблицы должны быть четкими и контрастнымив формате jpg, иметь разрешение не менее 300 dpi, подрисуночные надписи к ним должны быть расположены ниже рисунка по центру. Цветные рисунки, диаграммы не допускаются.

5. На рисунках должен быть минимум буквенных и цифровых обозначений, обязательно объясненных в статье или подрисуночных подписях.

6. Необъясненные сокращения слов, имен, названий, кроме общепринятых, не допускаются. Аббревиатуры расшифровываются после первого появления в тексте, например: Организация по экономическому сотрудничеству и развитию (ОЭСР).

7. Упомянутые в статьях единицы измерения должны соответствовать Международной системе единиц СИ.

8. Математические формулы должны быть набраны в Microsoft Education (каждая формула - один объект). Нумеровать следует лишь те формулы, на которые имеются ссылки.

9. Редакция не занимается литературной и стилистической обработкой статей. Материалы, статьи не возвращаются

10. Авторам для рассмотрения статьи необходимо представить рукопись на сайт www.sua.aesa.kz, и копию статьи со всеми сопроводительными документами согласно требованию направить на e-mail: zhurnal.aesa.99@ mail.ru :

10.1. Электронную версию статьи;

10.2.Наукометрическую базу данных для РИНЦ

10.3. Представить сканированную копию квитанцию об оплате за публикацию статьи и квитанцию об оплате за присвоение DOI (Digital Object Identifier) авторам, (только после подтверждения редакцией Журнала статьи к опубликованию).

ВНИМАНИЕ: DОI (Digital Object Identifier) присваивается регистрационным агентством International DOI Foundation (Интернэйщенел ДОИ Фаундэйщен). 